\title{
Pengaruh Pendidikan Kesehatan Pijat Bayi terhadap Kualitas Tidur Bayi Usia 0-6 Bulan di BPM Dewi Suyanti Tahun 2020
}

\author{
Saddiyah Rangkuti \\ Program Studi Kebidanan, Universitas Haji Sumatera Utara
}

\begin{tabular}{l} 
Info Artikel \\
\hline Article history: \\
Diterima 08-06-2021 \\
Revisi 22-06-2021 \\
Disetujui 09-07-2021
\end{tabular}

\section{Kata kunci:}

Pendidikan Kesehatan, Pijat bayi,

Kualitas tidur.

\begin{abstract}
A B S T R A K
Pijat bayi adalah pemijatan yang dilakukan dengan usapan-usapan halus pada permukaan kulit bayi, dilakukan dengan menggunakan tangan yang bertujuan untuk menghasilkan efek terhadap syaraf, otot, sistem pernafasan serta sirkulasi darah dan limpha, tujuan penelitian untuk mengetahui apakah terdapat pengaruh pendidikan kesehatan pijat bayi terhadap kwalitas tidur bayi umur 0-6 bln di BPM Dewi Suyanti Tahun 2020. Penelitian ini menggunakan jenis penelitian kuantitatif, dengan desain crosssectional, Desain penelitian ini menggunakan desain crosssectional, Populasi dalam penelitian adalah seluruh ibu yang memiliki bayi usia 0-6 bulan di klinik bersalin BPM Dewi Suyanti Tahun 2020 yaitu sebanyak 20 orang, sampel dalam penelitian ini total sampling seluruh ibu yang memiliki bayi usia 0-6 bulan sebanyak 20 bayi, dengan teknik penelitian menggunakan uji Chi Kuadrat. Hasil penelitian ini Ada pengaruh yang signifikan pendidikan kesehatan pijat bayi terhadap kualitas tidur pada bayi usia 0-6 bulan di di BPM Dewi Suyanti Tahun 2020, dengan nilai $\mathrm{p}$ value $=0,000(\mathrm{p}<0,05)$. Disarankan Bagi bidan di BPM Dewi Suyanti diharapkan dapat menyebarluaskan metode pemberian pijat bayi ini ke masyarakat, terutama bagi ibu-ibu yang baru melahirkan atau sedang melakukan imunisasi kepada bayinya sehingga ibu dapat melakukan teknik pijat bayi itu sendiri dan sedini mungkin kepada bayinya sebagai salah satu intervensi yang dapat membantu meningkatkan kualitas tidur bayi.
\end{abstract}

\section{Koresponden Penulis:}

Saddiyah Rangkuti,

Program Studi Kebidanan, Universitas Haji Sumatera Utara,

Jl. Rumah Sakit H., Medan Estate, Kec. Percut Sei Tuan, Kabupaten Deli Serdang, Sumatera Utara 20371.

Email: saddiyahrangkuti76@gmail.com

\section{PENDAhULUAN}

Pijat bayi adalah pemijatan yang dilakukan dengan usapan-usapan halus pada permukaan kulit bayi, dilakukan dengan menggunakan tangan yang bertujuan untuk menghasilkan efek terhadap syaraf, otot, sistem pernafasan serta sirkulasi darah dan limpha (Subakti dan Rizky, 2018).

Data WHO (Work Healty Organisasion) Amerika telah dilakukan penelitin pada sekelompok anak yang dilakukan pemijatan mengalami perubahan gelombang otak. Pada 20 anak yang dilakukan pemijatan selama $2 \times 15$ menit dalam jangka waktu 5 minggu mengalami $50 \%$ perubahan gelombang otak dibanding sebelum dipijat, perubahan gelombang otak ini terjadi dengan cara menrunkan gelombang alpha dan meningkatkan gelombang $\beta$ serta merta sehingga bayi akan tertidur lebih lelap (WHO, 2017).

Penelitian Di Touch Research Institusi Amerika juga menemukan bayi yang mendapatkan pijatan lebih aktif dan waspada,selain itu pijatan menyebabkan neurologis pada bayi yang dipijat lebih cepat matang dari pada bayi yang tidak dipijat. Anak-anak yang mendapatkan sentuhan penuh cinta kasih sejak usia dini mempunyai ketrampilan bahasa dan membaca, maupun IQ yang lebih kuat. Ini dibuktikkan pada kajian yang diselenggarakan di Rainbow Babies and Children's Hospital di Cleveland, Ohio. Suatu tim peneliti dari Warwick Medical School dan Institute of Education dari University of Warwick, meneliti 9 macam gerakan massage yang diterapkan kepada 598 bayi usia 6 
bulan. Dari hasil keluarnya hormon tidur melatonin, dimana dengan hormon tersebut bayi dapat memiliki pola tidur yang teratur (Roesli, 2017).

Pengamatan T. Field seperti dikutip dr. J. David Hull, menyebutkan terapi pijat 30 menit per hari bisa mengurangi depresi dan kecemasan, tidur bayipun bertambah tenang (Kautsar, 2016). Namun kenyataannya pijat bayi ini masih kurang dalam pelaksanaannya. Sebagian besar bayi dipijat hanya saat sakit saja oleh karena itu perlunya pengetahuan dan sikap ibu tentang manfaat pijat bayi pada bayi usia 6-12 bulan.

Beberapa rumah sakit di Amerika Serikat, Cina, Filipina, Hong Kong sudah memasukkan pijat bayi ke dalam sistem pelayanan kesehatan. Beberapa rumah sakit di Indonesia yang sudah memasukkan pijat bayi ke dalam sistem pelayanan adalah beberapa Rumah Sakit/Rumah Bersalin di Surabaya, Yogyakarta, Jakarta, Bandung dan Medan. Pemijatan dilakukan oleh bidan. Pijat bayi diyakini merupakan salah satu stimulasi sentuhan (touch) yang bisa membantu mengoptimalkan pertumbuhan bayi (Subakti,2016)

Pijatan bayi merupakan salah satu cara yang menyenangkan untuk menghilangkan ketegangan dan kerewelannya. Karena pijatan lembut akan membantu mengendurkan otot-ototnya, sehingga ia menjadi tenang dan tertidur. Pemijatan terhadap bayi oleh ibunya sendiri juga mempunyai makna sendiri, karena sangat berpengaruh terhadap hubungan batin atau hubungan kejiwaan antara ibu dengan bayi. Bagi sang bayi, pijatan ibu dapat dirasakan sebagai sentuhan kasih sayang yang sangat berarti bagi pembentukan kepribadiannya kelak di kemudian hari.Melalui sentuhan pemijatan terhadap jaringan otot, peredaran darah dapat meningkat ke jaringan otot ataupun posisi otot dapat dipulihkan dan diperbaiki, sehingga dapat meningkatkan fungsi-fungsi organ tubuh dengan sebaik-baiknya (Subakti dan Rizky, 2018).

Kemampuan dan tumbuh kembang anak perlu dirangsang oleh orang tua agar anak dapat tumbuh dan berkembang secara optimal dan sesuai umurnya. Stimulasi adalah perangsangan yang datang dari lingkungan anak. Anak yang mendapat stimulasi yang terarah akan lebih cepat berkembang dibandingkan dengan anak yang kurang atau bahkan tidak mendapat stimulasi ( Ronald, 2017).

Studi tentang bayi telah menunjukkan bahwa sentuhan, gerakan dan juga suara akan merangsang jalan syaraf, selain itu juga akan mempercepat pertumbuhan jaringan syaraf. Penambahan berat badan akan semakin cepat dan aktifitas sel akan ditingkatkan bersamaan dengan meningkatnya fungsi endokrin (Turner, 2017).

Sentuhan dan pijat pada bayi setelah kelahiran dapat memberikan jaminan adanya kontak tubuh berkelanjutan yang dapat mempertahankan perasaan aman pada bayi. Laporan tertua tentang seni pijat untuk pengobatan tercatat di Papyrus Ebers, yaitu catatan kedokteran zaman Mesir Kuno. Ayur-Veda buku kedokteran tertua di India (sekitar 1800 SM ) yang menuliskan tentang pijat, diet, dan olah raga sebagai cara penyembuhan utamamasa itu. Sekitar 5000 tahun yang lalu para dokter di Cina dari Dinasti Tang juga meyakini bahwa pijat adalah salah satu dari 4 teknik pengobatan penting ( Roesli, 2016).

Pemijatan tidak hanya bermanfaat untuk bayi tetapi juga untuk pemberi pijatan, ini adalah alat yang akan membebaskan diri dari stres dan merupakan alat untuk membangun ikatan antar orangtua dan juga ikatan antara orangtua dengan bayi. Manfaat lain dari pemijatan pada bayi adalah meningkatnya keyakinan pemberi pijatan dalam mengurus bayi itu (Turner, 2017).

Ilmu kesehatan modern telah membuktikan secara ilmiah bahwa terapi sentuhan dan pijat pada bayi mempunyai banyak manfaat terutama bila dilakukan sendiri oleh orangtua bayi. Penelitian tentang pengaruh pijat bayi terhadap kenaikan berat badan bayi memperoleh hasil bahwa pada kelompok kontrol kenaikan berat badan sebesar 6,16\% sedangkan pada kelompok yang dipijat 9,44\% ( Putri, 2016).

Tidur adalah salah satu bentuk adaptasi bayi terhadap lingkungannya. Sesaat setelah lahir, bayi biasanya tidur selama 16-20 jam sehari. Memasuki usia 2 bulan bayi mulai lebih banyak tidur malam dibanding siang. Sampai usia 3 bulan, bayi baru lahir akan menghabiskan waktu tidurnya sekitar 15-17 jam, dengan pembagian waktu 8 jam untuk tidur siang dan 9 jam untuk tidur malam. Semakin usia bayi bertambah, jam tidurnya juga semakin berkurang. Pada usia 3-6 bulan jumlah tidur siang semakin berkurang, kira-kira 3 kali. Total jumlah waktu tidur bayi 
usia 0-6 bulan berkisar antara 13-15 jam/hari. Pada bayi usia 6 bulan pola tidurnya mulai tampak mirip dengan orang dewasa (Gola, 201)

Tidur nyenyak sangat penting bagi pertumbuhan bayi, karena saat tidur pertumbuhan otak bayi mencapai puncaknya. Selain itu pada saat tidur tubuh bayi memproduksi hormon pertumbuhan tiga kali lebih banyak dibandingkan ketika bayi terbangun (Gola, 2016).

Menurut Sekartini (2014), dengan jumlah responden 285 bayi, diperoleh data 51,3\% bayi mengalami gangguan tidur, $42 \%$ bayi tidur malamnya kurang dari 9 jam, dan pada malam hari bayi terbangun lebih dari 3 kali dengan lama bangun lebih dari satu jam.

Salah satu terapi non farmakologis untuk mengatasi masalah tidur bayi adalah pijat bayi (Liaw, 2000 dalam Hikmah, 2016). Pijat bayi bermanfat untuk meningkatkan konsentrasi bayi dan membuat bayi tidur lelap. Selain itu pijat bayi juga bermanfaat untuk meningkatkan pertumbuhan dan berat badan bayi, meningkatkan produksi ASI, serta meningkatkan daya tahan tubuh (Subakti, 2018).

Pijat bayi adalah terapi sentuh tertua yang dikenal manusia yang paling populer. Pijat bayi telah lama dilakukan hampir di seluruh dunia, termasuk di Indonesia, dan diwariskan secara turun temurun. (Roesli, 2017)

Sentuhan dan pijat pada bayi setelah kelahiran dapat memberikan jaminan adanya kontak tubuh berkelanjutan yang dapat mempertahankan perasaan aman pada bayi. Laporan tertua tentang seni pijat untuk pengobatan tercatat di Papyrus Ebers, yaitu catatan kedokteran zaman mesir kuno, Ayur- Veda buku kedokteran tertua di India(sekitar 1800 sebelum Masehi) yang menuliskan tentang pijat, diet dan olahraga sebagai cara penyembuhan utama masa itu. Sekitar 5000 tahun yang lalu para dokter di cina dari Dinasti Tang juga meyakini bahwa pijat adalah salah satu 4 teknik pengobatan penting. (Roesli, 2017)

Tidur adalah hal yang penting (meskipun kita tidak tahu persis apa alasannya). Meskipun bertahun-tahun telah diadakan penelitian yang serius, para ilmuwan belum sepenuhnya memahami tujuan tidur sesungguhnya.Beberapa ilmuwan percaya bahwa tidur itu terjadi ketika kita beralih dari memori-memori yang pendek menuju memori-memori yang panjang.Tidur sepertinya juga bisa meningkatkan system kekebalan kita, mungkin itulah mengapa kita merasa seperti banyak tidur ketika kita sedang sakit dan mengapa kita lebih rentan terserang flu, sakit tenggorokan, dan beberapa infeksi yang biasa lainnya ketika kita terlalu lelah. Pada bayi tidur mungkin bisa memberi kontribusi pada perkembangan otak, menjaga dan mengatur semua kemampuan yang luar biasa dan informasi yang mereka serap setiap hari. Penelitian juga telah menunjukkan bahwa anak-anak mengalami pertumbuhan saat tidur (Heildenberg, 2016).

Fenomena yang terjadi dalam kajian akhir-akhir ini menyatakan bahwa kurang dari $20 \%$ dari kelompok bayi berusia 6-12 bulan yang dapat tidur tanpa terbangun sedikitnya satu kali diantara tengah malam dan jam 5 pagi (Kelly, 2002). Dan dari hasil penelitian yang dilakukan oleh Sekartini R,dkk. Mengenai masalah tidur pada bayi dan balita yang disebarkan di Jakarta, Bandung, Medan, Palembang, Batam pada tahun 2014-2017, terungkap bahwa 72,2 \% orang tua menganggap masalah tidur pada bayi dan balita adalah masalah kecil, padahal apabila si kecil terganggu masalah tidurnya maka pertumbuhan dan perkembangan yang optimal akan sulit dicapai (Sekartini, 2017).

Penelitian yang dilakukan oleh Ajeng Mahardika Wati tahun 2016 dengan judul penelitian pengaruh pendidikan kesehatan tentang pijat bayi terhadap praktik pijat bayi (the effect of health education to baby massage skill ) di dapatkan hasil penelitian menunjukkan bahwa nilai p-value sebesar 0.000 dan nilai $\alpha<0.005$. Sehingga pada penelitian dapat disimpulkan ada pengaruh pendidikan kesehatan tentang pijat bayi terhadap praktik pijat bayi oleh ibu bayi. Hal ini di dukung oleh metode yang dipakai dalam memberikan pendidikan kesehatan ini menggunakan metode ceramah dan mendemonstrasikan atau mempraktikkan secara langsung langkah memijat bayi yang baik dan benar. Materi yang disampaikan sesuai dengan kebutuhan responden dan dalam penyampaian pendidikan kesehatan menggunakan alat bantu berupa leaflet dan audio visual berupa rekaman video dalam bentuk compact disc tentang cara memijat bayi yang baik dan benar.

Penelitian yang dilakukan oleh Ekawati tahun 2018 dengan judul penelitian pengaruh pendidikan kesehatan terhadap pengetahuan dan perilaku pemberian pijat bayi oleh ibu di brajan

JURKESMAS : Jurnal Kesehatan Masyarakat, Vol. 1, No. 1, Juli 2021: 34 - 42 
tamantirto bantul yogyakarta Ada pengaruh yang signifikan antara pendidikan kesehatan tentang pijat bayi terhadap pengetahuan ibu tentang pijat bayi di Brajan Tamantirto Bantul Yogyakarta. Ada pengaruh yang signifikan antara pendidikan kesehatan tentang pijat bayi terhadap perilaku ibu dalam melakukan pijat bayi di Brajan Tamantirto Bantul Yogyakarta.

Survey awal yang dilakukan di BPM Dewi Suyanti Tahun 2020 melalui wawancara langsung BPS dewi membuka praktik pijat bayi. Dari 10 ibu tersebut masih banyak ibu bayi yang belum mengetahui manfaat lebih jauh dari pijat bayi dan belum memahami bagaimana memijat bayi yang benar sehingga tidak bisa melakukan pemijatan secara mandiri. Alasan ibu memijatkan bayinya karena bayi sedang sakit batuk, rewel dan terjatuh dan iu menyatakan belum mendapatkan pendidikan kesehatan tentang pijat bayi. Maka, dari latar belakang tersebut penulis ingin meneliti tentang pengaruh pendidikan kesehatan tentang pijat bayi terhadap praktik pijat.

\section{METODE PENELITIAN}

Penelitian ini dilakukan di BPM Dewi Suyanti. Wilayah Dewi Suyanti. BPM Dewi Suyanti merupakan bentuk pelayanan kesehatan dibidang kesehatan dasar sesuai dengan kewenangan dan kemampuan bidan. BPM Dewi Suyanti memberikan pelayanan selama 24 jam untuk masyarakat, dan memiliki tempat dan ruangan praktek yang memenuhi persyaratan kesehatan, mempunyai tempat tidur untuk persalinan dan memiliki 5 tempat tidur, memiliki peralatan yang sesuai dengan ketentuan dan menyediakan obat-obatan sesuai dengan ketentuan yang berlaku

\section{HASIL DAN PEMBAHASAN}

\subsection{Hasil}

Deskripsi hasil penelitian ini mencakup data kualitas tidur bayi usia 0-6 bulan di BPM Dewi Suyanti sebelum dilakukan pijat bayi dan sesudah dilakukan pijat bayi. Sampel dalam penelitian ini adalah ibu yang memiliki bayi usia 0-6 bulan yaitu sebanyak 20 responden. Selanjutnya responden diberikan kuesioner untuk mengetahui pengaruh pendidikan kesehatan pijat bayi terhadap kualitas tidur bayi sebelum dilakukan pendidikan kesehatan pijat bayi dan sesudah dilakukan pendidikan kesehatan pijat bayi. Langkah berikutnya dilakukan teknik analisis data univariat untuk mencari distribusi frekuensi dari setiap variabel dan análisis bivariat untuk mencari pengaruh pendidikan kesehatan pijat bayi terhadap kualitas tidur bayi usia 0-6 bulan di BPM Dewi Suyanti Tahun 2020.

\section{Analisa Univariat}

Berdasarkan hasil penelitian pada bayi bayi usia 0-6 bulan di BPM Dewi Suyanti Tahun 2020 diketahui data karakteristik responden berdasarkan umur, jenis kelamin, dan berat badan yang diperoleh dari 20 bayi. Hasil data karakteristik responden disajikan dalam bentuk tabel dibawah ini:

Tabel 1. Data Karakteristik Bayi di BPM Dewi Suyanti Tahun 2020

\begin{tabular}{llll}
\hline No & Data Demografi & Frekuensi & Presentase (\%) \\
\hline $\mathbf{1}$ & Umur & & \\
& 3 bulan & 6 & 30,0 \\
& 4 bulan & 9 & 45,0 \\
& 5 bulan & 3 & 15,0 \\
& 6 bulan & 2 & 10,0 \\
\hline & Jumlah & 20 & 100 \\
\hline $\mathbf{2}$ & Jenis Kelamin & & \\
& Laki-laki & 9 & 45,0 \\
& Perempuan & 11 & 55,0 \\
\hline & Jumlah & 20 & 100 \\
\hline
\end{tabular}

Berdasarkan tabel 1 di atas, data karakteristik bayi usia 0-6 bulan di BPM Dewi Suyanti Tahun 2020 mayoritas berumur 3 bulan sebanyak 11 responden (36,7\%), dan berjenis kelamin perempuan sebanyak 16 bayi $(54,3 \%)$.

Sedangkan untuk berat badan bayi didapatkan data sebagai berikut :

Tabel 2. Data Rata-rata Berat Badan Bayi 0-6 Bulan di BPM Dewi Suyanti Tahun 2020

\begin{tabular}{lllll}
\hline Data & Rata-rata & Standar Deviasi & Min & Max \\
\hline $\begin{array}{l}\text { Berat Badan } \\
\text { Bayi }\end{array}$ & 4,525 & 0,512 & $3,6 \mathrm{~kg}$ & $5,7 \mathrm{~kg}$ \\
\hline
\end{tabular}


Berdasarkan tabel 2 di atas, diketahui bahwa rata-rata berat badan bayi antara usia 0-6 bulan adalah sebesar 4,525 kg dengan berat badan maksimal seberat 5,7 $\mathrm{kg}$ dan berat minimal seberat 3,6 $\mathrm{kg}$.

Data kualitas tidur pada bayi usia 0-6 bulan sebelum diberikan pendidikan kesehatan pijat bayi di BPM Dewi Suyanti Tahun 2020 dapat dilihat pada tabel 3 berikut :

Tabel 3. Kualitas Tidur Pada Bayi Usia 0-6 Bulan Sesudah Diberikan Pendidikan Kesehatan Pijat Bayi di BPM Dewi Suyanti Tahun 2020

\begin{tabular}{ccc}
\hline Kualitas Tidur Bayi 0-6 bulan & Frekuensi & \% \\
\hline Baik & 1 & 5,0 \\
Cukup & 9 & 45,0 \\
Kurang & 10 & 50,0 \\
\hline Jumlah & $\mathbf{2 0}$ & $\mathbf{1 0 0}$
\end{tabular}

Berdasarkan tabel 3 di atas diketahui bahwa kualitas tidur bayi usia 0-6 bulan sebelum dilakukan pijat mayoritas memiliki kualitas tidur yang kurang yaitu sebanyak 10 bayi (50\%).

Data kualitas tidur pada bayi usia 0-6 bulan sesudah diberikan pendidikan kesehatan pijat bayi di BPM Dewi Suyanti Tahun 2020 dapat dilihat pada tabel 4 berikut :

Tabel 4. Kualitas Tidur Pada Bayi Usia 0-6 Bulan Sesudah dilakukan pijat bayi di BPM Dewi

Suyanti Tahun 2020

\begin{tabular}{ccc}
\hline Kualitas Tidur Bayi 0-6 bulan & Frekuensi & \% \\
\hline Baik & 11 & 55,0 \\
Cukup & 9 & 45,0 \\
Kurang & 0 & 0,0 \\
\hline Jumlah & $\mathbf{2 0}$ & $\mathbf{1 0 0}$ \\
\hline
\end{tabular}

Berdasarkan tabel 4 di atas diketahui bahwa kualitas tidur bayi usia 0-6 bulan sesudah dilakukan pijat mayoritas memiliki kualitas tidur yang baik yaitu sebanyak 11 bayi $(55,0 \%)$.

\section{Analisa Bivariat}

Analisis bivariat pada bagian ini menyajikan hasil pengaruh pendidikan kesehatan pijat bayi terhadap kualitas tidur pada bayi usia 0-6 bulan di BPM Dewi Suyanti Tahun 2020, sebelum dan sesudah dilakukan pijat bayi. Untuk mengetahui pengaruh tersebut ini dilakukan uji wilcoxon.

Tabel 5. Pengaruh Pendidikan Kesehatan Pijat Bayi Terhadap Kualitas Tidur Bayi Umur 0-6 Bulan di BPM Dewi Suyanti Tahun 2020

\begin{tabular}{|c|c|c|c|c|c|}
\hline \multirow{3}{*}{$\begin{array}{l}\text { Kualitas Tidur Bayi 0-6 } \\
\text { Bulan }\end{array}$} & \multicolumn{2}{|c|}{ Perlakuan } & \multirow{2}{*}{\multicolumn{2}{|c|}{ Perubahan Ranking }} & \multirow{2}{*}{$p$ value } \\
\hline & Sebelum & Sesudah & & & \\
\hline & f & $\mathbf{F}$ & & $\mathbf{F}$ & \\
\hline - Baik & 1 & 11 & Rangking Positif & 0 & \multirow{3}{*}{$0,000 *$} \\
\hline - Cukup & 9 & 9 & Rangking Negatif & 15 & \\
\hline - Kurang & 10 & 0 & Ties & 5 & \\
\hline
\end{tabular}

Keterangan : a) Uji Wilcoxon

Perubahan Kualitas Tidur Bayi 0-6 bulan:

a. Ranking Negatif adalah perubahan kualitas tidur bayi sebelum dan sesudah dari kategori 'kurang' menjadi kategori 'cukup dan baik'

b. Ranking Positif adalah perubahan kualitas tidur bayi sebelum dan sesudah dari kategori 'baik' menjadi 'cukup' atau 'kurang'

c. Ties artinya tidak terjadi perubahan kualitas tidur bayi sebelum dan sesudah

Berdasarkan tabel 5 di atas menunjukan kualitas tidur bayi usia 0-6 bulan sebelum dan sesudah diberikan pendidikan kesehatan pijat bayi mengalami perubahan. Kualitas tidur bayi sebelum diberikan pendidikan kesehatan pijat bayi sebanyak 10 responden masuk dalam kategori kurang dan menjadi tidak ada sesudah dilakukan pijat bayi. Sedangkan kualitas tidur sebelum pendidikan kesehatan pijat bayi sebanyak 1 responden masuk dalam kategori baik dan setelah diberikan pendidikan kesehatan pijat bayi, kualitas tidur bayi yang baik bertambah menjadi 11 responden.

Berdasarkan Hasil uji statistic dengan menggunakan Uji Wilcoxon diketahui bahwa nilai $\mathrm{p}$ $(0,000)<\alpha(0,05)$ artinya Ho ditolak, jadi terdapat perbedaan yang signifikan kualitas tidur bayi usia 
0-6 bulan sebelum diberikan pendidikan kesehatan pijat bayi dengan yang sesudah diberikan pendidikan kesehatan pijat bayi. Dengan demikian disimpulkan bahwa ada pengaruh yang signifikan pendidikan kesehatan pijat bayi terhadap kualitas tidur pada bayi usia 0-6 bulan di BPM Dewi Suyanti Tahun 2020.

\subsection{Pembahasan}

Hasil penelitian didapatkan hasil kualitas tidur pada bayi usia 0-6 bulan sebelum diberikan pendidikan kesehatan pijat bayi sebagian besar memiliki kualitas tidur yang kurang yaitu sebanyak 10 bayi (50\%) dari 20 bayi yang diteliti. Kualitas tidur yang kurang ditandai oleh kualitas tidur bayi dengan tidur malam $\leq 9$ jam atau bahkan 3 jam sekali terbangun dan sering terbangun $\geq 3$ kali serta lama terbangunnya $\geq 1$ jam dan juga bayi rewel saat bangun pagi.

Hasil penelitian didukung oleh penelitian Layyinatus Shofa, dkk (2014), menunjukkan bayi usia 0-6 bulan di Poliklinik Kesehatan Desa Purworejo Kecamatan Bonang Kabupaten Demak sebelum dilakukan pemijatan bayi rata-rata kualitas tidurnya buruk. Sebelum bayi dipijat bayi sering rewel dan menangis sebelum tidur, bahkan bayi sering terbangun ketika tidur. Hal ini yang menyebabkan kualitas tidur bayi menjadi buruk.

Kualitas tidur bayi usia 3 -6 bulan tidak hanya berpengaruh pada perkembangan fisik, tapi juga sikapnya keesokan hari. Bayi usia 0-6 bulan yang tidur cukup tanpa sering terbangun akan lebih bugar dan tidak gampang rewel. Bayi dikatakan mengalami gangguan tidur jika pada malam hari tidurnya kurang dari 9 jam, terbangun lebih dari 3 kali dan lama terbangunnya lebih dari 1 jam. Selama tidur bayi terlihat selalu rewel, menangis dan sulit tidur kembali (Wahyuni, 2015)

Hasil penelitian menunjukkan bayi sebelum di pijat memiliki kualitas tidur yang kurang. Hal ini dapat dikarenakan bayi mengalami keletihan fisik yang disebabkan karena bayi suka dibawabawa atau digendong oleh orangtuanya maupun orang lain sehingga mengalami keletihan fisik. Bayi yang mengalami keletihan fisik akan sulit tidur dan akan mudah rewel jika akan tidur serta dalam tidurnya bayi tidak bisa nyenyak dan mudah terbangun. Terlebih lagi biasanya karena umur tersebut masih kecil bayi suka dibawa-bawa orangtuanya sehingga dengan begitu banyak kuman diluar sana mudah akan jatuh sakit sehingga dapat mempengaruhi kualitas tidurnya (Hidayat, 2012).

Hal ini didukung oleh teori Heath dan Bainbridge (2007), kualitas tidur bayi yang rendah ini dapat dikarenakan keletihan akibat aktivitas fisik yang dilakukan bayi selama 24 jam. Menurut Perry \& Potter (2009), dampak fisiologi meliputi penurunan aktivitas sehari-hari, rasa capai, lemah, koordinasi neoromuskular buruk, proses penyembuhan lambat dan daya tahan tubuh menurun. Sedangkan dampak psikologimya meliputi emosi lebih labil, cemas, tidak konsentrasi, kemampuan kognitif dan menggabungkan pengalamannya lebih rendah.

Hasil penelitian menunjukkan bahwa kualitas tidur pada bayi usia 0-6 bulan sesudah diberikan pendidikan kesehatan pijat bayi rata-rata memiliki kualitas yang baik yaitu sebanyak 11 bayi $(55,0 \%)$. Hasil tersebut menunjukkan bahwa kualitas tidur bayi setelah dilakukan pijat bayi mengalami keadaan tidur malam $\geq 9$ jam, terbangun $\leq 3$ kali, lama terbangunnya $\leq 1$ jam dan bayi tidak rewel saat bangun pagi. Akan tetapi masih terdapat 13 bayi (40\%) yang memiliki kualitas tidur yang cukup dengan keadaan bayi tidur malam $\leq 9$ jam dan terbangun $\geq 3$ kali dan lama terbangunnya $\geq 1$ jam dan bayi tidak rewel saat bangun pagi, Hasil penelitian membuktikan bahwa pijat bayi berpengaruh terhadap kualitas tidur bayi usia 0-6 bulan, dimana dengan dilakukannya pijat bayi membuat kualitas tidur bayi menjadi lebih baik dengan keadaan tidur malam malam $\geq 9$ jam, terbangun $\leq 3$ kali, lama terbangunnya $\leq 1$ jam dan bayi tidak rewel saat bangun pagi.

Bayi setelah dilakukan pemijatan menunjukkan peningkatan kualitas tidurnya. Hal ini terjadi karena pijat dapat mempunyai efek positif pada kesehatan bayi. Efek dari tindakan pijat bayi ini adalah mengendalikan hormon stress, sehingga bayi yang diteliti, memiliki efek seperti mudah tertidur dan membuat perasaan nyaman bagi bayi. Pijatan lembut akan membantu meringankan ketegangan otot sehingga bayi menjadi tenang dan tertidur. Bayi yang kualitas tidurnya baik juga dipengaruhi oleh lingkungan bayi yang tidak terisik serta suasana kamar yang lebih nyaman.

Berdasarkan hasil penelitian dapat dijelaskan bahwa pijat bayi merupakan salah satu cara yang membuat perasaan nyaman bagi bayi karena pijatan lembut akan membantu meringankan ketegangan otot sehingga bayi menjadi tenang dan tertidur. Pijatan pada bayi membantu otak anak memproduksi hormone oksitosin, yang menurunkan kadar stres dalam otaknya. Dengan kata lain, 
pijatan bayi bisa membantunya relaks, mengurangi lama ia menangis dan membantunya tidur. Pemijatan juga akan meningkatkan tonus vagal sehingga merangsang saraf vagus. Suplai saraf parasimpatis dihantarkan ke dan dari abdomen melalui saraf vagus. Saraf vagus adalah saraf kepala kesepuluh yang mengatur fungsi organ tubuh termasuk dibagian dada dan perut. Rangsangan pada saraf vagus (saraf parasimpatis) akan merangsang sel enterochromaffin dalam saluran gastrointestinal untuk mengeluarkan hormon serotonin (Guyton dan Hall, 2007).

Berdasarkan hasil analisis data menunjukan kualitas tidur bayi usia 0-6 bulan sebelum dan sesudah diberikan pendidikan kesehatan pijat bayi mengalami perubahan. Kualitas tidur bayi sebelum diberikan pendidikan kesehatan pijat bayi sebanyak 10 responden masuk dalam kategori kurang dan menjadi tidak ada sesudah dilakukan pijat bayi. Sedangkan kualitas tidur sebelum pendidikan kesehatan pijat bayi sebanyak 1 responden masuk dalam kategori baik dan setelah diberikan pendidikan kesehatan pijat bayi, kualitas tidur bayi yang baik bertambah menjadi 11 responden.

Berdasarkan Hasil uji statistic dengan menggunakan Uji Wilcoxon diketahui bahwa nilai p $(0,000)<\alpha(0,05)$ artinya Ho ditolak, jadi terdapat perbedaan yang signifikan kualitas tidur bayi usia 0-6 bulan sebelum diberikan pendidikan kesehatan pijat bayi dengan yang sesudah diberikan pendidikan kesehatan pijat bayi. Dengan demikian disimpulkan bahwa ada pengaruh yang signifikan pendidikan kesehatan pijat bayi terhadap kualitas tidur pada bayi usia 0-6 bulan di BPM Dewi Suyanti Tahun 2020.

Hasil penelitian sesuai dengan penelitian Layyinatus Shofa, dkk (2014), menunjukkan bahwa terdapat pengaruh pijat bayi teradap kualitas bayi usia 0-6 bulan di Poliklinik Kesehatan Desa Purworejo Kecamatan Bonang Kabupaten Demak. Berdasarkan hasil penelitian dari hasil kuaesioner yang di isi ibu masing-masing bayi didapatkan data bahwa bayi mereka tidurnya lebih tenang, bayi tidak rewel dan nafsu makannya juga meningkat. Namun pada penelitian ini terdapat beberapa faktor yang ikut berpengaruh dalam peningkatan kualitas tidur bayi sehingga menyebabkan hasil penelitian yang tidak berbeda secara bermakna. Faktor-faktor tersebut mencakup lingkungan dan penyakit. Lingkungan yang ramai dan tidak kondusif akan mempengaruhi kualitas tidur bayi tersebut. Pada penelitian ini faktor lingkungan tidak dikendalikan secara ketat, sehingga menimbulkan pengaruh pula terhadap kualitas tidurnya. Sedangkan penyakit atau kesehatan bayi. Ada satu bayi yang mengalami sakit influenza dan batuk pada saat diberi perlakuan pemijatan sehingga pemijatan dihentikan dan dilanjutkan ketika bayi sudah sehat kembali.

Pemijatan juga meningkatkan mekanisme penyerapan makanan oleh nervus vagus sehingga nafsu makan bayi juga meningkat. Berdasarkan data pendukung dari hasil wawancara dengan ibu masing-masing bayi didapatkan data bahwa bayi mereka tidurnya lebih tenang. Hal ini sesuai dengan pendapat Wahyuni (2015) bahwa kualitas tidur bayi tidak hanya berpengaruh pada perkembangan fisik, tapi juga sikapnya keesokan hari. Bayi yang tidur cukup tanpa sering terbangun akan lebih bugar dan tidak gampang rewel dan tidak memerlukan tidur siang yang melebihi kebutuhan sesuai dengan perkembangannya.

Keadaan tenang dan rileks menyebabkan gelombang otak melambat, semakin lambat akhirnya membuat seseorang dapat beristirahat dan tertidur. Perubahan gelombang otak yang terjadi adalah penurunan gelombang alpha dan peningkatkan gelombang beta theta, dimana gelombanggelombang otak tersebut sangat berpengaruh dalam proses tidur (Yahya, 2011).

Berdasarkan data pendukung dari hasil wawancara dengan ibu masing-masing bayi didapatkan data bahwa bayi mereka tidurnya lebih tenang, bayi tidak rewel ketika bangun tidur, buang air besar lancar dan nafsu makannya juga meningkat dalam mengkonsumsi air susu ibu (ASI). Hal ini sesuai dengan pendapat Roesli (2009) bahwa pemijatan dapat meningkatkan kadar serotonin yang akan menghasilkan melatonin yang berperan dalam tidur dan membuat tidur lebih lama dan lelap pada malam hari. Seperti yang telah dijelaskan di atas, serotonin juga akan meningkatkan kapasitas sel reseptor yang berfungsi mengikat glukokortikoid (adrenalin, suatu hormon stress). Proses ini menyebabkan terjadinya penurunan kadar hormon adrenalin (hormon stress) sehingga bayi yang diberi perlakuan pemijatan akan tampak lebih tenang dan tidak rewel. 


\section{KESIMPULAN}

Kualitas Tidur Pada Bayi Usia 0-6 Bulan sebelum diberikan pendidikan kesehatan pijat bayi di BPM Dewi Suyanti Tahun 2020 mayoritas memiliki kualitas tidur yang kurang. Kualitas Tidur Pada Bayi Usia 0-6 Bulan sesudah diberikan pendidikan kesehatan pijat bayi di BPM Dewi Suyanti Tahun 2020 mayoritas memiliki kualitas tidur yang cukup. Ada pengaruh yang signifikan pendidikan kesehatan pijat bayi terhadap kualitas tidur pada bayi usia 0-6 bulan di di BPM Dewi Suyanti Tahun 2020 , dengan nilai $\mathrm{p}$ value $=0,000(\mathrm{p}<0,05)$.

\section{REFERENCES}

Ajeng Mahardika Wati, 2016," pengaruh pendidikan kesehatan tentang pijat bayi terhadap praktik pijat bayi (the effect of health education to baby massage skill )"

Ardhillah, City, Azz. 2017. Segalanya Bayi, Kupas Tuntas Ilmu Bayi A-Z.Yogyakarta: Syura Mediautama

Arikunto. 2017. Prosedur Penelitian Suatu Pendekatan Praktik. Jakarta: Rineka Cipta

Azwar.S.2017, Sikap Manusia Teori Dan Pengukuran. Yogyakarta. Pustaka pelajar

Ekawati, 2018, "pengaruh pendidikan kesehatan terhadap pengetahuan dan perilaku pemberian pijat bayi oleh ibu di brajan tamantirto bantul, yogyakarta

Hartini. 2016. Kebutuhan Tidur Bayi Dan Anak-Anak. http://berbagisehat.com/index.php/advertorial/index.php?view=artickdancatid=99=baby-atoddler\&id=319=kebutuhantidur bayidanformat=Pdf (diakses tanggal 19 April 2017 jam $10.00 \mathrm{WIB})$

Heildenberg, Steven, M.D. 2016. Buku Pintar Perawatan Bayi. Jakarta: Prestasi Pustaka raya.

Hidayat, AA. 2017. Pengantar Ilmu Keperawatan Anak Untuk Pendidikan Kebidanan. Jakarta: Salemba Medika.

Indriatie. 2016. Pengaruh Pijat Bayi Terhadap Kualitas Tidur Bayi Usia 6-12 Bulan Di Polindes Jiyu-Kutorejo Mojokerto.

Maryunani, Anik. 2017. Ilmu Kesehatan Anak dalam Kebidanan. Jakarta: Trans Info Media

Putri, A 2019, Pijat dan Senam untuk Bayi \& Balita, Deniua Publisher, Yogyakarta.

Mubarak, W.I 2017, Promosi Kesehatan Untuk Kebidanan. Jakarta . Salemba Medika

Nazwa, N.U. 2017. Rahasia Ibu Pintar, Panduan Merawat Bayi Pasca Persalinan Sampai 12 Bulan. Yogyakarta: Katahati

Notoadmodjo, S. ,2016, Sikap Manusia. Jakarta: Rineka Cipta

Notoatmodjo. 2017. Metodologi Penelitian Kesehatan. Jakarta: Rineka Cipta

Nursalam. 2018. Konsep dan Penerapan Metodologi Penelitian Ilmu Keperawatan. Jakarta: Salemba Medika

Roesli. U 2019, Pedoman Pijat Bayi, Trubus Agriwidya, Jakarta

Ronald, HS 2011, Pedoman \& Perawatan Balita Agar Tumbuh Sehat dan Cerdas, Nuansa Aulia, Bandung

Turner, R 2010, Pedoman Praktis Pemijatan Bayi, Kharisma, Tangerang pengaruh pendidikan kesehatan pijat bayi terhadap kwalitas tidur bayi umur 0-6bln dBPM Dewi Suyantitahun 2020

Prasetyono. 2016. Teknik-Teknik Memijat Bayi Sendiri. Yogyakarta: Diva Press Riksani, Ria. 2017. Cara Mudah dan Aman Pijat Bayi. Jakarta: Dunia Sehat Roesli, Utami. 2017. Pedoman Pijat Bayi. Jakarta: PT. Trubus Agriwidya Salsabila, Salwa. 2016. Tips Cerdas Merawat Bayi. Yogyakarta: Luna Publisher

Santi, Enidya. 2017. Buku Pintar Pijat Bayi Untuk Tumbuh Kembang Optimal Sehat dan Cerdas. Yogyakarta: Pinang Merah Publisher

Saryono, 2017. Metodelogi penelitian kebidanan. D-III, D-IV, SI dan S2. Yogyakarta Nuha medika Sekartini, Rini, 2017. Buku Pintar Bayi. Jakarta: Pustaka Bunda

Soedjatmiko. 2016. Pijat bayi seberapa penting. http//www.republik.com.httm (diakses pada 19 April 2017 jam 10.00 WIB)

Subakti dan Deri, Rizky. 2016. Keajaiban Pijat Bayi Dan Balita. Jakarta : Wahyu Media

Sugiono. 2017. Statistika Untuk Penelitian. Bandung. ALFABETA 
Wahyuni, 2017. Hubungan Pijat Bayi Dengan Kualitas Tidur Bayi Umur 6-12 Bulan Di Desa Kertosari Kecamatan Singorojo Kabupaten Kendel.Skripsi.PSIK.UMS.Semarang 